\title{
Blasts 15 Percent or Less of Bone Marrow Nucleated Cells
}

National Cancer Institute

\section{Source}

National Cancer Institute. Blasts 15 Percent or Less of Bone Marrow Nucleated Cells. NCI Thesaurus. Code C160963.

A semi-quantitative microscopic finding indicating that at most 15 percent of the nucleated cells in a bone marrow sample are immature mononuclear cells. 